\title{
CREATINE KINAZA AS TRANSIENT MUSCULAR DAMAGE INDICATOR - ANALYZES AND IMPORTANCE FOR TECHNOLOGY OF SPORTS TRAINING
}

\author{
Bojana Marić \\ University of Novi Sad, Faculty of Sport and Physical Education, student DAS, \\ Army of Serbia, Ministry of Defense of the Republic of Serbia
}

\begin{abstract}
SUMMARY
Previous research suggests that there is no single marker that would be sufficiently reliable indicator of muscle damage and overtraining. Monitoring several physiological indicators can lead to the desired response. Among them is the creatine kinase serum as one of the best indicators of muscle damage accompanying physical activity. In addition to other properties, it is a direct indicator of muscle damage and overtraining. The aim of this paper is the organization of knowledge published in relevant scientific journals that directly concern creatine kinase and its relation with other markers, as well as the limit of its use. By measuring the level of creatine kinase before and after exercise, the existence of myopathy without muscle biopsy can be predetermined, which is one of the most important functions of this serum. In the future, research should include other factors that indicate muscle damage and overtraining, their synergistic activity, and new findings in assessing transient muscle damage due to physical activity.
\end{abstract}

Keywords: CREATINE KINAZA / PREVENTION / DAMAGE OF MUSCLE / SPORT

\section{INTRODUCTION}

Location of creatine kinase $(\mathrm{CK})$ is in the sarcolemma and mitochondrial intermembrane space of healthy muscle cells. CK catalyzes the movement of phosphate from phosphocreatine to adenosine diphosphate, forming adenosine triphosphate (ATP) and creatine (Anugweje, Okonko, 2012). When we talk about isoforms, there is a several isoforms of CK: three isoenzymes in the cytoplasm (CK-MM, CK$\mathrm{MB}, \mathrm{CK}-\mathrm{BB})$, and two isoenzymes in mitochondria.

The best indirect indicator of muscle damage is serum enzyme activities of creatine kinase, which leads to damaged muscle circulation (Brancaccio at all., 2010, Nigro et al., 1983). When we talk about sport and physical activity, the concentration of serum creatine kinase is one of the main indicators of damage skeletal muscles (Mougios, 2014). In response to a physical activity, even though the serum CK varies among individuals, its blood level is certainly widely used as an indicator to reflect the muscle breakdown
(Heled et al., 2007). Muscle damage due to physical activity characterized by delayed onset muscle soreness [DOMS], increasing the level of muscle protein in the blood and reduced muscle function, especially in people who are not on the level of given training (Gomes et al., 2014).

The first characteristic of muscle disorder is pain, fatigue, weakness, and increases in serum CK (Brancaccio et al., 2010). High CK level can be produced by many factors: alcohol, heat, dehydration, drugs, stress and crush trauma (Clarkson et al., 2006). On the other hand, there is a possibility that the CK response after physical activity depends on personal abilities and training background. Therefore, the focus of investigation should be correlation between serum $\mathrm{CK}$ level following the exercises and body structure and other characteristics of the individual (Fehrenbach et al., 2010).

Previous studies were based mainly on long-distance runners and most activity data CK coming analyzing these athletes, although it has been estab- 
lished that short intensive interval activities stimulate growth in serum CK, especially if it is an eccentric muscular contraction (Fehrenbach et al., 2010). High serum levels of CK is the result of cracking sarkolemal membrane and has been correlated with the extent and intensity of exercise, and is related to the severity of muscle soreness (Brancaccio et al., 2010).

\section{FACTORS THAT DETERMINE THE DYNAMICS AND INTENSITY OF CREATINE KINASE SERUM}

The level of CK activity depends on the sex, muscle mass, volume and intensity of exercise, as well as the individual physical condition (Malaguti et al., 2009). In a study of CK level in trained and untrained individuals, it was higher in people who were trained, regardless of sex and age (Heled et al., 2007). There are gender differences in the level of CK at rest, where more enzymes are observed in men. Lower values in women appear after exercise, which, according to some studies, is the result of estrogen that prevents leakage of serum CK from damaged muscle (Haramizu et al., 2011).

Some research suggests that there is a difference in the oxidative stress and antioxidant protection during aging. In examining the effect of exercise on the level of $\mathrm{CK}$ in the elderly, the results indicate that exercise in the elderly increases the level of markers that induce muscle damage, as well as markers of oxidative stress (Brancaccio et al., 2007), therefore elderly people are not equally subject to muscle damage compared to young people (Newham et al., 1987).

In the newborn, CK serum levels are higher than those in adults and are dependent on gestational age, with values that reach adult levels within the first 10 days of life (Clarkson et al., 2006). In early pregnancy, the level of CK is increased in order to reduce the period of late pregnancy, however, remain high levels of CK-MB (Brancaccio et al., 2007).

Young adult males have high serum levels of CK, which decline slightly with age during the geriatric period (Brancaccio et al., 2007).

In relation to race, black men has higher CK levels compared to Caucasians, although some studies have shown that there are no racial differences in the level of CK in athletes, despite the fact that black people generally tend to and have a higher density of bones than white people (Brancaccio et al., 2007).
Therefore, the values of CK show great variability among individuals. Some athletes have lower reactions to physical activity with chronic low serum CK levels. Other athletes have a high level of response with higher values of this enzyme. There is a breaking point at a CK concentration of 300-500 IU / 1 when it is released into the blood after physical activity. The level of CK enzyme depends on muscle characteristics (Brancaccio et al., 2007). Schumann and Klauk (Schumann, Klauke 2003) proposed the limit values of CK which are 350 in men and $200 \mathrm{IU} / 1$ in women. The second study shows different limits for men, 391 and $398 \mathrm{IU} / \mathrm{l}$ and 240 and $207 \mathrm{IU} / \mathrm{l}$ for women (Mougios, 2007). The main difference between the results of individual studies is probably due to the different level of training of the respondents, as well as athletes of different sports branches and disciplines involved in the research. Namely, if athletes and non-athletes are doing the same physical activity test, the serum level of CK athletes is lower than those observed with the control group of non-athletes (Nigro et al., 1983, Anugweje, Okonoko, 2012). Also, a large increase in serum CK levels combined with reduced tolerance to effort can be a marker of overtraining (Anugweje, Okonoko, 2012). The release time of CK depends primarily on the level of training, type, intensity and duration of the activity. After prolonged exercise, activity of total serum CK increases significantly during the 24 hours after exercise. However, if an athlete continues to practice, the level of CK may remain much longer (Clarkson, Hubal, 2008). The highest values of serum CK occur 8 hours after power training.

\section{CREATINE KINASE IN ATHLETES OF VARIOUS SPORTS BRANCHES AND DISCIPLINES}

High serum CK was observed after long-term physical activity such as ultramarathon (Fehrenbach et al., 2010), Ironman triathlon (Neubauer et al., 2008) and triathlon (Brancaccio et al., 2010), where after these activities it is inevitable muscle collapse. Ultratriatlon is associated with high changes in CK activity (54 to $1849 \mathrm{IU} / 1$ ), as well as changes in other markers of muscle damage (Gastmann et al., 1998). Most of the serum CK monitoring data comes from long-bugs, but there are also studies that show that 
the short physical activity of an eccentric type of muscle contraction increases the level of CK (Brancaccio et al., 2007).

Mougios and colleagues (Mougios et al., 2007) measured CK activity in footballers and swimmers, where the lowest reference level for footballers was 83 IU / 1, while for swimmers it was about $70 \mathrm{IU} / 1$. The upper limit was in the order of 1492 and $523 \mathrm{IU} / \mathrm{l}$.

Major changes in the CK as a marker of muscle damage $\left(\sim 900 \mathrm{IU} \bullet \mathrm{l}^{-1}\right)$, as well as a fall after 20 meters of the sprint test $(-2 \%)$ and a maximum jump $(-10 \%)$ after 24 hours of the match, was observed in elite young football players (Fatouros et al., 2010). There was also a significant increase in CK activity ( $1000 \mathrm{IU} \bullet 1^{-1}$ ), after the rugby match (Takarada, 2003). In the study of Hovatson and Milak (Howatson, Milak, 2009), the conditions of muscle inflammation and activity of CK $\left(\sim 800 \mathrm{IU} \bullet \mathrm{l}^{-1}\right)$ are monitored, 24 hours after 15 sprints at 30 meters in young athletes. Moreira and colleagues (Moreira et al., 2014) in their study suggest that the analyzed basketball game leads to small muscle inflammation and there is no significant release of proteins from the muscle after that. These data can also indicate that top athletes are resistant to large CK oscillations and possible transitional damage to the muscles. Gil and colleagues (Gill et al., 2006) followed rugby players and found that the level of CK before and after the match was very high, in the order of 1023.0 (308.3) and 2194.0 (833.7) IU / 1. Negative consequences of muscle damage in tennis players with reduced production of strength were also noted, which can affect performance during the match (Gomes et al., 2014). The highest values of each player in the study ranged from 105 to $498 \mathrm{IU}$ - $1^{-1}$, and a significant increase in plasma CK activity was recorded 24 hours and 48 hours after the match.

\section{LEVEL OF SERUMA CK - CHALLENGE FOR SPORTS AND TECHNOLOGY OF TRAINING}

In order to increase exercise performance and reduce muscle damage, studies and research try to figure out the most effective way to recover the body after physical activity. For that purpose, there are numerous supplements and methods that have been found in practice, with or without justified reasons.

\section{Hydration state and creatine kinase}

There are numerous studies related to the use of liquids during the training process (water, juices, energy drinks), as well as studies dealing with the effect of dehydration on the body and physical performance. Ozkan and Ibrachim (Ozkan, Ibrachim, 2016) examined whether there is a difference between wrestlers that are and which are not dehydrated and found that there is a high serum CK in the dehydrated group, which had a negative impact on muscle pain performance. The second study examined the consumption of green tea during exercise and concluded that green tea is an excellent antioxidant, and that it reduces the release of CK during exercise (Kuo et al., 2015). By consuming black currant juice after high-intensity training, it reduces damage and muscle inflammation by reducing CK 48 to 96 hours after exercise (Hutchison et al., 2016). Consumption of electrocytically modified water significantly reduces muscular damage caused by exercise and accelerates recovery (Borsa et al., 2013).

\section{Supplementation and creatine kinase levels}

One of the supplements in the reduction of muscle damage, and therefore the level of serum CK activity, which is widely used in recovery after high-intensity activities is creatine (Kim et al., 2015). A combination of amino acids supplements from the group BCAA (branched chain amino acid) and taurine, as well as preparations from the group of anti-inflammatory and antioxidant acids, can be an effective means of delaying muscle inflammation and muscle damage (Ra et al., 2013). On the other hand, the same authors concluded that the addition of taurine alone does not affect the level of CK in healthy individuals after exercise. Fouré and colleagues (Fouré et al., 2010) found that the damaged muscle was unable to take advantage of the BCAA consuming after exercise. Also, another study concludes that supplements with amino acids before and after 100 kilometers of ultramarathon also have no effect on serum CK levels (Knechtle et al., 2011). Consumption of curcumin increases the strength and duration of exercise and reduces the level of CK after physical activity (Huang et al., 2015), also relieves muscle inflammation, which is associated with a lower blood CK (Nicol et al., 2015) and reduces muscle damage to the syringes induced exercise (McFarlin et al., 2016). Supplementation of the saffron (10 days for $300 \mathrm{mg}$ ) also has a preventative effect on muscle inflammation and significantly 
reduces the concentration of $\mathrm{CK}$, and 4 grams of ginger after exercise simplifies the recovery of the body, but does not affect the damage and delay of muscle inflammation (Matsumura et al., 2015 ).

\section{Cryotherapy and creatine kinase}

According to recent research, the treatment of dipping in cold water has no effect as previously thought. Takeda and colleagues (Takeda et al., 2014) did not find that cold water has an effect on the level of CK after rugby and football match. Immersion in cold water immediately after 24 hours did not influence the observed indicators of physical performance (Rupp et al., 2012), that is, only the immersion of the body follows minimal effects on the deposition of muscle inflammation (Glasgow et al., 2014). However, Machado and colleagues (Machado et al., 2016) indicate that immersion in the water temperature between 11 and $15^{\circ} \mathrm{C}$ for a time of 11 to 15 minutes may have an effect.

\section{Creatine kinase and effects of massage and vibration therapy}

There is no clear record of the effects of massage in combination with hypoxia compared to using only massage at the CK level after a football game (Gatterer et al., 2013). Whole-body vibration therapy after exercise shows lower pressure, pain and muscle inflammation with less reduction in maximal isometric and isokinetic muscle strength and lower blood creatine kinase levels (Veqar, Imtiyaz, 2014). In contrast, vibration therapy is not more effective than standard massage and stretching when it comes to the level of CK after exercise (Fuller et al., 2015).

\section{OTHER MARKERS AND MUSLE DAMAGE}

Considering previous research and findings, we can conclude that there is no single marker that can be considered an indicator of damage and overtrain. Because of that investigators recommend using more than one marker to provide the answer. Creatine kinase, lactate dehydrogenase, aldolase, aspartate transferase myoglobin, troponin and carbonic anhydrase are the most useful serum markers of muscle injury (Brancaccio et al., 2010). The more markers you consider, you get more precise results.
Serum lactate dehydrogenase (LDH) activity is a marker of cell damage, and it increases in isoenzymes may be useful for the diagnosis in non-traumatic acute rhabdomyolysis (Brancaccio at al., 2010).

Aldolase can be used in conjunction with CK to assess the condition of adaptation muscles in training (Brancaccio et al., 2010). In chronic muscular injuries, both aspartate transferase (AST) and alanine aminotransferase (ALT) (Nathwani et al., 2005) have been increased and is rarely increased in non-sick people and having normal CK activity, suggesting the existence of AST macroenzymes Cabrera-Abrev et al., 2008).

In some athletes, the increase in serum AST should be considered together with the activity of CK (Brancaccio et al., 2010). Mioglobin is a useful marker for monitoring the efficacy of muscle tissue loading at training (Speranza et al., 2007).

Studies have found that in myopathy, there is a close correlation between $\mathrm{TnT}$ (one of two troponin isoforms) and CK (Collinson et al., 1995). In patients with chronic muscular disease, the concentration of TnT (Prellwitz et al., 1996) increased.

Carbonic anhydrase III is another useful marker of muscle damage because it is present in the skeletal muscle but not in the myocardium and is released into the bloodstream after injury (Fu et al., 2009). Increasing and decreasing its concentration is faster than in aldolase, CK, AST and LDH (Shima, 1984). Whatever marker is taken into consideration, complementing one or more of them will only show more accurate results, since none of them, by itself, is sufficient to reliably conclude.

\section{LIMITATIONS IN THE APPLICATION OF CREATINE KINASE MONITORING RESULTS}

In the diagnosis of diseases of the brain, heart and muscle activity, CK is widely used as a marker of possible disease condition (Brancaccio et al., 2006). In normal conditions, in the serum of skeletal muscle there is only CK-MM, CK-BB is mostly found in the brain and, CK-MB is cardiac isoenzym. On the other hand, there are cases when other enzymes, beside CK-MM, can be found in skeletal muscle, such as CK-MB in ultramarathon runners (Denvir at al., 1999) and CK-BB in boxers (Brancaccio et al., 2007). The CK level grows 6 hours after exercise and can stay 
elevated and two days after exercise. If after these periods the presence of these isoenzymes in the muscles continues to be, it is about some nonphysiological condition. Some people who have very high levels of $\mathrm{CK}$ after exercising may have some kind of muscular disease requiring additional analysis. Increased levels of CK levels in healthy non-athletes require further research (Brancaccio et al., 2006).

The level of CK can also be elevated by drug consumption, asthma, hypothyroidism, the use of anabolic steroids (Dekkers et al., 1996). If there is an increase in CK levels and atypical symptoms, muscle biopsy is the best way of diagnosis. So far, it has determined that: $18 \%$ of these patients suffer from muscular disease, almost 39\% have atypical muscular anomalies, while the rest of the subjects were of normal health (Stanhouders et al., 1999). One of the most important role of creatine kinase is the fact that monitoring its level before and after exercise can point to myopathy and without muscle biopsy, which is a far more invasive method (Brancaccio et al., 2010). However, the increase in serum levels of the CK does not necessarily result from exercise and damage to muscles caused by exercise. On the other hand, there are athletes who do not have any symptoms of applied sports activities. By increasing the intensity and volume of exercise, such athletes can be accessed, but in this case there is a possibility of a negative effect of prolonged exercise and training in the form of loss of muscle proteins (Brancaccio et al., 2006).

\section{NEW INDICATORS IN ASSESSMENT OF TRANSIENT MUSCLE DAMAGE}

New discoveries should go in the direction of more precise detection of muscle damage, finding a faster, more accurate, discriminatory and specific marker that would be affordable, easily measurable and inexpensive, whose measurement indicates only transitional damage to the muscles without linking with possible pathological conditions organism. The practice lacks a marker that would be efficient and with a lower amplitude of measured values, as is the case so far (Brancaccio et al., 2011). Such a marker should indicate differences in gender, individual differences and the same differences regardless of which part of the body is subjected to physical activity (Koch et al., 2014). In view of this, an accurate and unified measurement protocol should be defined, which has not been the case so far. One of the future markers, which is in the process of research and detection and which could replace the rest of the known markers of muscle damage, is gonidine acetic acid (GAA). As a natural creatine precursor, in the conditions when creatinine availability is undisturbed, the role of GAA as a substrate is negligible, while, on the other hand, in the case of creatine deficiency, it can fully saturate creatine kinase and act as a replacement phosphagen (Ostojić, 2015). The results of the study that examined the impact of endurance training (treadmill training) and repetitive strength training (benchmark-to-failure) on the level of GAA and creatine obtained results suggest that creatine levels increased in both types of exercise, especially when running, as and that the concentration of GAA dropped significantly in both cases, more in running training (Steier et al., 2016). The conclusion of this study is precisely that in the future the serum level of GAA can be used as a new fatigue biomarker in the physically active population.

\section{CONCLUSION}

Creatine kinase (CK) is one of several markers of muscle damage caused by exercise. The CK level remains raised 24 hours after exercise, after which it returns to the initial level. If, after that time, it continues to be elevated, it is probably overtraining. In addition, muscle damage may occur after physiological and pathological conditions. A better evaluation and a compact picture of the muscle state give a blood test and urine.

The level of creatine kinase depends on a number of factors, such as sex, race, body weight, physical activity, etc. A high level of CK in healthy people is mainly associated with training.

The highest values of CK were found mainly in longrunners and long training, such as ultramaratone, activities that require eccentric muscle contraction.

The assessment of CK before and after physical activity is a "diagnostic tool" for the detection of myopathy, which is far less invasive than necessary for muscle biopsy. This is probably the most important use of serum creatine kinase for diagnostic purposes in sports and physical activity. 


\section{REFERENCES}

1. Anugweje, K. C., \& Okonko, I. O. (2012). Effect of Noni Supplementation on the Serum Creatine Kinase (CK) Levels of Athletes. World J. Sport Sci., 7, 41-47.

2. Borsa, P. A., Kaiser, K. L., \& Martin, J. S. (2013). Oral consumption of electrokinetically modified water attenuates muscle damage and improves postexercise recovery. Journal of Applied Physiology, 114(12), 1736-1742.

3. Brancaccio, P., Limongelli, F. M., \& Maffulli, N. (2006). Monitoring of serum enzymes in sport. British journal of sports medicine, 40(2), 96-97.

4. Brancaccio, P., Lippi, G., \& Maffulli, N. (2010). Biochemical markers of muscular damage. Clinical Chemistry and Laboratory Medicine, 48(6), 757-767.

5. Brancaccio, P., Maffulli, N., \& Limongelli, F. M. (2007). Creatine kinase monitoring in sport medicine. British medical bulletin, 81(1), 209-230.

6. Brancaccio, P., Maffulli, N., Politano, L., Lippi, G., \& Limongelli, F. M. (2011). Persistent HyperCKemia in Athletes. Muscles, ligaments and tendons journal, 1(1), 31.

7. Cabrera-Abreu, J., Jain, R., Robinson, P., Edees, S., \& Staughton, T. (2008). A case of aspartate aminotransferase macroenzyme. Annals of clinical biochemistry, 45(3), 320-322.

8. Clarkson, P. M., \& Hubal M. J. (2008). Exercise-induced muscle damage in humans. American journal of physical medicine \& rehabilitation, 81(11): 52-69.

9. Clarkson, P. M., Kearns A. K., Rouzier, P., Rubin, R., \& Thompson, P. D.(2006). Serum creatine kinase levels and renal function measures in exertional muscle damage. Medicine and science in sports and exercise. 38(4): 623.

10. Collinson,P.O., Chandler,H.A., Stubbs, P.J., Moseley, D.S., Lewis, D., \& Simmons, M.D. (1995). Measurement of serum troponin T, creatine kinase $\mathrm{MB}$ isoenzyme, and total creatine kinase following arduous physical training. Ann Clin Biochem 32: 450-3.

11. Dekkers,J.C., van Doornen, L.J., \& Kemper, H.C. (1996). The role of antioxidant vitamins and enzymes in the prevention of exercise induced muscle damage. Sports Med, 21: 213-38.
12. Denvir, M.A., Galloway, P.J., Meighan, A.S., Blyth, M., Alexander, C., \& Fleming, C. (1999). Changes in skeletal and cardiac muscle enzymes during the Scottish Coast to Coast Triathlon. Scott Med J, 44: 49-51.

13. Fatouros, I. G., Chatzinikolaou, A., Douroudos, I. I., Nikolaidis, M. G., Kyparos, A., Margonis, K., ... \& Mandalidis, D. (2010). Time-course of changes in oxidative stress and antioxidant status responses following a soccer game. The Journal of Strength \& Conditioning Research, 24(12), 3278-3286.

14. Fehrenbach, E., Niess, A. M., Schlotz, E., Passek, F., Dickhuth, H. H., \& Northoff, H. (2000). Transcriptional and translational regulation of heat shock proteins in leukocytes of endurance runners. Journal of Applied Physiology, 89(2), 704-710.

15. Fouré, A., Nordez, A., \& Cornu, C. (2010). Plyometric training effects on Achilles tendon stiffness and dissipative properties. Journal of Applied Physiology, 109(3), 849-854.

16. Fu, F., Nie, J., \& Tong, T. K. (2009). Serum cardiac troponin $\mathrm{T}$ in adolescent runners: effects of exercise intensity and duration. International journal of sports medicine, 30(03), 168-172.

17. Fuller, J. T., Thomson, R. L., Howe, P. R., \& Buckley, J. D. (2015). Vibration therapy is no more effective than the standard practice of massage and stretching for promoting recovery from muscle damage after eccentric exercise. Clinical Journal of Sport Medicine, 25(4), 332-337.

18. Gastmann, U., Dimeo, F., Huonker, M., Bocker, J., Steinacker, J. M., Petersen, K. G., ... \& Lehmann, M. (1998). Ultra-triathlon-related blood-chemical. J Sports Med Phys Fitness, 38, 18-23.

19. Gatterer, H., Schenk, K., Wille, M., Murnig, P., \& Burtscher, M. (2013). Effects of massage under hypoxic conditions on exercise-induced muscle damage and physical strain indices in professional soccer players. Biology of sport, 30(2), 81.

20. Gill, N. D., Beaven, C. M., \& Cook, C. (2006). Effectiveness of post-match recovery strategies in rugby players. British journal of sports medicine, 40(3), 260-263. 
21. Glasgow, P. D., Ferris, R., \& Bleakley, C. M. (2014). Cold water immersion in the management of delayed-onset muscle soreness: Is dose important? A randomised controlled trial. Physical therapy in sport, 15(4), 228-233.

22. Gomes, R. V., Santos, R. C. O., Nosaka, K., Moreira, A., Miyabara, E. H., \& Aoki, M. S. (2014). Muscle damage after a tennis match in young players. Biology of sport, 31(1), 27.

23. Haramizu, S., Ota, N., Hase, T., \& Murase, T. (2011). Catechins attenuate eccentric exercise-induced inflammation and loss of force production in muscle in senescence-accelerated mice. Journal of Applied Physiology, 111(6), 1654-1663.

24. Heled, Y., Bloom, M. S., Wu, T. J., Stephens, Q., \& Deuster, P. A. (2007). CM-MM and ACE genotypes and physiological prediction of the creatine kinase response to exercise. Journal of Applied Physiology, 103(2), 504-510.

25. Howatson, G., \& Milak, A. (2009). Exercise-induced muscle damage following a bout of sport specific repeated sprints. The Journal of Strength \& Conditioning Research, 23(8), 2419-2424.

26. Huang, W. C., Chiu, W. C., Chuang, H. L., Tang, D. W., Lee, Z. M., Wei, L., ... \& Huang, C. C. (2015). Effect of curcumin supplementation on physiological fatigue and physical performance in mice. Nutrients, 7(2), 905-921.

27. Hutchison, A. T., Flieller, E. B., Dillon, K. J., \& Leverett, B. D. (2016). Black currant nectar reduces muscle damage and inflammation following a bout of high-intensity eccentric contractions. Journal of dietary supplements, 13(1), 1-15.

28. Kim, J., Lee, J., Kim, S., Yoon, D., Kim, J., \& Sung, D. J. (2015). Role of creatine supplementation in exercise-induced muscle damage: A mini review. Journal of exercise rehabilitation, 11(5), 244.

29. Knechtle, B., Knechtle, P., Mrazek, C., Senn, O., Rosemann, T., Imoberdorf, R., \& Ballmer, P. (2011). No effect of short-term amino acid supplementation on variables related to skeletal muscle damage in $100 \mathrm{~km}$ ultra-runners-a randomized controlled trial. Journal of the International Society of Sports Nutrition, 8(1), 6.

30. Koch, A. J., Pereira, R., \& Machado, M. (2014). The creatine kinase response to resist- ance exercise. J Musculoskelet Neuronal Interact, 14(1), 68-77.

31. Kuo, Y. C., Lin, J. C., Bernard, J. R., \& Liao, Y. H. (2015). Green tea extract supplementation does not hamper endurance-training adaptation but improves antioxidant capacity in sedentary men. Applied Physiology, Nutrition, and Metabolism, 40(10), 990-996.

32. Machado, A. F., Ferreira, P. H., Micheletti, J. K., de Almeida, A. C., Lemes, Í. R., Vanderlei, F. M., ... \& Pastre, C. M. (2016). Can water temperature and immersion time influence the effect of cold water immersion on muscle soreness? A systematic review and meta-analysis. Sports Medicine, 46(4), 503-514.

33. Malaguti, M., Angeloni, C., Garatachea, N., Baldini, M., Leoncini, E., Collado, P. S., ... \& Hrelia, S. (2009). Sulforaphane treatment protects skeletal muscle against damage induced by exhaustive exercise in rats. Journal of Applied Physiology, 107(4), 1028-1036.

34. Matsumura, M. D., Zavorsky, G. S., \& Smoliga, J. M. (2015). The effects of pre-exercise ginger supplementation on muscle damage and delayed onset muscle soreness. Phytotherapy Research, 29(6), 887-893.

35. McFarlin, B. K., Venable, A. S., Henning, A. L., Sampson, J. N. B., Pennel, K., Vingren, J. L., \& Hill, D. W. (2016). Reduced inflammatory and muscle damage biomarkers following oral supplementation with bioavailable curcumin. $B B A$ clinical, 5, 72-78.

36. Meamarbashi, A., \& Rajabi, A. (2015). Preventive Effects of 10-Day Supplementation With Saffron and Indomethacin on the Delayed-Onset Muscle Soreness. Clinical Journal of Sport Medicine, 25(2), 105-112.

37. Moreira, A., Nosaka, K., Nunes, J. A., Viveiros, L., Jamurtas, A. Z., \& Aoki, M. S. (2014). Changes in muscle damage markers in female basketball players. Biology of sport, 31(1), 3 .

38. Mougios, V. (2007). Reference intervals for serum creatine kinase in athletes. British journal of sports medicine, 41(10), 674-678.

39. Nathwani, R. A., Pais, S., Reynolds, T. B., \& Kaplowitz, N. (2005). Serum alanine aminotransferase in skeletal muscle diseases. Hepatology, 41(2), 380-382.

40. Neubauer, O., König, D., \& Wagner, K. H. (2008). Recovery after an Ironman triathlon: 
sustained inflammatory responses and muscular stress. European journal of applied physiology, 104(3), 417-426.

41. Newham, D. J., Jones, D. A., \& Clarkson, P. M. (1987). Repeated high-force eccentric exercise: effects on muscle pain and damage. Journal of Applied Physiology, 63(4), 1381-1386.

42. Nicol, L. M., Rowlands, D. S., Fazakerly, R., \& Kellett, J. (2015). Curcumin supplementation likely attenuates delayed onset muscle soreness (DOMS). European journal of applied physiology, 115(8), 1769-1777.

43. Nigro, G., Comi, L. I., Limongelli, F. M., Giugliano, M. A. M., Politano, L., Petretta, V., ... \& Stefanelli, S. (1983). Prospective study of $\mathrm{X}$-linked progressive muscular dystrophy in campania. Muscle \& nerve, 6(4), 253-262.

44. Ostojić, S. M. (2015). Cellular bioenergetics of guanidinoacetic acid: the role of mitochondria. Journal of bioenergetics and biomembranes, 47(5), 369-372

45. Ozkan, I., \& Ibrahim, C. H. (2016). Dehydration, skeletal muscle damage and inflammation before the competitions among the elite wrestlers. Journal of physical therapy science, 28(1), 162-168.

46. Prellwitz, W., Hafner, G., Rupprecht, H. J., \& Meyer, J. (1996). Diagnostic and differential diagnostic value of troponins. Medizinische Klinik (Munich, Germany: 1983), 91(6), 336-342.

47. Ra, S. G., Miyazaki, T., Ishikura, K., Nagayama, H., Komine, S., Nakata, Y., ... \& Ohmori, H. (2013). Combined effect of branchedchain amino acids and taurine supplementation on delayed onset muscle soreness and muscle damage in high-intensity eccentric exercise. Journal of the International Society of Sports Nutrition, 10(1), 51.

48. Rupp, K. A., Selkow, N. M., Parente, W. R., Ingersoll, C. D., Weltman, A. L., \& Saliba, S. A. (2012). The effect of cold water immersion on 48-hour performance testing in collegiate soccer players. The Journal of Strength \& Conditioning Research, 26(8), 2043-2050.
49. Schumann, G., \& Klauke, R. (2003). New IFCC reference procedures for the determination of catalytic activity concentrations of five enzymes in serum: preliminary upper reference limits obtained in hospitalized subjects. Clinica chimica acta, 327(1-2), 69-79.

50. Shima, K. (1984). Human muscle carbonic anhydrase III (CA-III). Purification, immunohistochemical localization in the human skeletal muscle and its clinical application to the neuromuscular disease. [Hokkaido igaku zasshi] The Hokkaido journal of medical science, 59(2), 98-116.

51. Speranza, L., Grilli, A., Patruno, A., Franceschelli, S., Felzani, G., Pesce, M., ... \& Felaco, M. (2007). Plasmatic markers of muscular stress in isokinetic exercise. Journal of biological regulators and homeostatic agents, 21(1/2), 23.

52. Stadhouders, A. M., Jap, P. H., Winkler, H. P., Eppenberger, H. M., \& Wallimann, T. (1994). Mitochondrial creatine kinase: a major constituent of pathological inclusions seen in mitochondrial myopathies. Proceedings of the National Academy of Sciences, 91(11), 50895093.

53. Štajer, V., Trivic, T., Drid, P., Vranes, M., \& Ostojic, S. M. (2016). A single session of exhaustive exercise markedly decreases circulating levels of guanidinoacetic acid in healthy men and women. Applied Physiology, Nutrition, and Metabolism, 41(10), 1100-1103.

54. Takarada, Y. (2003). Evaluation of muscle damage after a rugby match with special reference to tackle plays. British journal of sports medicine, 37(5), 416-419.

55. Takeda, M., Sato, T., Hasegawa, T., Shintaku, H., Kato, H., Yamaguchi, Y., \& Radak, Z. (2014). The effects of cold water immersion after rugby training on muscle power and biochemical markers. Journal of sports science \& medicine, 13(3), 616.

56. Veqar, Z., \& Imtiyaz, S. (2014). Vibration therapy in management of delayed onset muscle soreness (DOMS). Journal of clinical and diagnostic research: JCDR, 8(6), LE01. 


\title{
CREATINA QUINASA COMO INDICADOR DEL DAÑO TRANSITORIO DE LOS MÚSCULOS - ANÁLISIS Y SIGNIFICADO PARA LA TECNOLOGÍA DE ENTRENAMIENTO DEPORTIVO PRINT-A-MAIL
}

\begin{abstract}
Resumen
Las investigaciones de hasta el momento demuestran que no existe un marcador único que sería el indicador suficientemente fiable del daño muscular y de sobreentrenamiento. Seguir varios indicadores fisiológicos puede llevar hasta la respuesta deseada. Entre ellos está también el suero de creatina quinasa como uno de los mejores indicadores del daño muscular que acompaña la actividad física. Además de otras características, ella es el indicador directo del daño muscular y de sobreentrenamiento. El objetivo del presente trabajo es organizar los conocimientos publicados en las revistas científicas relevantes, referidos directamente a la creatina quinasa y sus vínculos con otros marcadores, así como también, el límite de su uso. Midiendo el nivel de creatina quinasa antes y después de los ejercicios se puede predeterminar la existencia de miopatía sin la biopsia del musculo, lo que es una de las funciones más importantes de este suero. En el futuro, las investigaciones deberían abarcar también otros factores que indican los daños musculares y sobreentrenamiento, su actividad sinérgica, pero también nuevos descubrimientos en la estimación de los daños musculares transitorios por la actividad física.
\end{abstract}

Palabras claves: CREATINA QUINASA/ SOBREENTRENAMIENTO/ DAÑO MUSCULAR /DEPORTE/ TECNOLOGÍA DE ENTRENAMIENTO

Received: 02.10.2017.

Accepted: 27.11.2017. 


\title{
КРЕАТИН КИНАЗА КАО ИНДИКАТОР ПРОЛАЗНОГ ОШТЕЋЕЊА МИШИЋА - АНАЛИЗА И ЗНАЧЕЊЕ ЗА ТЕХНОЛОГИЈУ СПОРТСКОГ ТРЕНИНГА
}

\author{
Бојана Марић \\ Универзитет у Новом Саду, Факултет спорта и физичког васпитања, студент ДАС и \\ Министарсто одбране Републике Србије, Београд
}

\begin{abstract}
Сажетак
Досадашња истраживања указују на то да не постоји јединствен маркер који би био довољно поуздан показатељ оштећења мишића и претренираности. Праћење неколико физиолошких индикатора може довести до жељеног одговора. Међу њима је и серум креатин киназе као један од најбољих индикатора оштећења мишића, која прате физичку активност. Он је, поред осталих својстава, директан показатељ оштећења мишића и претренираности. Циљ овог рада је организација знања публикованих у релевантним научним часописима, а која се директно тичу креатин киназе и његових веза са другим маркерима, као и лимит његовог коришћења. Мерењем нивоа креатин киназе, пре и после вежбања, може се предодредити постојање миопатије без биопсије мишића, што је једна од најважнијих функција овог серума. У будућности, истраживања би требало да обухвате и друге факторе који указују на мишићна оштећења и претренираност, њихово синергично деловање, али и нова открића у процени пролазних оштећења мишића услед физичке активности.
\end{abstract}

КљУчне речи: КРЕАТИН КИНАЗА/ ПРЕТРЕНИРАНОСТ/ ОШТЕЋЕЮЕ МИШИЋА/ СПОРТ / ТЕХНОЛОГИЈА ТРЕНИНГА

\section{УВОД}

Креатин киназа (СК) се налази у сарколеми и митохондријалном интермембранском простору здравих мишићних ћелија. Он катализује кретање фосфата из фосфокреатина на аденозин дифосфат, формирајући аденозин трифосфат (АТР) и креатин (Anugweje, Okonko, 2012). Најмање пет изоформи СК постоје: три изоензима у цитоплазми (СК-ММ, СК-МВ, СК-ВВ), и два изоензима у митохондријама.

Серумске активности ензима креатин киназе које улазе у циркулацију и које су резултат мишићног метаболизма користе се као, тренутно, најбољи индиректни маркери мишићног оштећења (Brancaccio et al., 2010, Nigro et al., 1983). Концентрација серумске креатин киназе регистрована у циркулацији се широко користи као индекс оштећења скелетних мишићних влакана при физичкој активности (Mougios, 2007). Иако концентрација СК варира између појединаца, његов ниво у крви се широко користи као индикатор мишићног оштећења при физичкој активности (Heled et al., 2007). Транзиционо оштећење мишића услед физичке активности карактерише одложен мишићни бол (delayed onset muscle soreness, DOMS), повећан ниво мишићних протеина у крви и смањење мишићне функције, посебно код људи који нису припремљени за задати ниво тренинга (Gomes et al., 2014).

Примарни показатељ оштећења скелетних мишића манифестује се кроз бол, умор, слабост и повећање серумског СК (Brancaccio et al., 2010). Висок ниво СК може бити узрок и многих других фактора као што су: алкохол, висока температура, дехидратација, дрога, стрес и разне трауме (Clarkson et al., 2006). Такође, одговор креатин киназе при вежбању зависи и од физичких карактеристика појединца, као и од начина живота 
и вежбања. Стога, потребне су детаљне студије о повезаности серума СК након вежбања како са телесном композицијом и другим карактеристикама појединца, тако и са стањем његове физичке кондиције (Fehrenbach et al., 2000).

Већина података о нивоу серума СК код спортиста резултат су праћења дугопругаша, мада је утврђено да и кратке интензивне интервалне активности подстичу раст у серуму СК, нарочито ако се ради о ексцентричној мишићној контракцији (Fehrenbach et al., 2000). Висок ниво серума СК последица је оштећења сарколеме. Оштећење је вероватно пропорционално трајању и интензитету контракције, а односи се на степен мишићне осетљивости (Brancaccio et al., 2010).

\section{ФАКТОРИ КОЈИ ОДРЕБУЈУ ДИНАМИКУ И ИНТЕНЗИТЕТ СЕРУМА КРЕАТИН КИНАЗЕ}

Ниво СК активности зависи од пола, мишићне масе, обима и интензитета вежбања, као и индивидуалних физичких карактеристика (Malaguti et al., 2009). У студији која се бавила нивоом ЦК код тренираних и нетренираних особа, утврђено је да је ниво ЦК виши код људи који тренирају, без обзира на пол и старост (Heled et al., 2007). Постоје полне разлике које се уочавају током мировања, где се запажају више вредности овог ензима код мушкараца. Ниже вредности код жена се појављују након вежбања, што је, према неким истраживањима, резултат естрогена који спречава „цурење“ серума ЦК из оштећеног мишића (Haramizu et al., 2011).

Нека истраживања упућују на разлике у концентрацији овог ензима при оксидативном стресу и услед промена у антиоксидативној заштити током старења. При истраживању утицаја вежбе на ниво СК код старијих особа, резултати указују на то да се вежбањем, код старијих особа повећава ниво маркера који индукују на оштећење мишића, као и маркери оксидативног стреса (Brancaccio et al., 2007), стога старији људи нису подједнако подложни оштећењима мишића у поређењу са младим особама (Newham et al., 1987).

Концентрација серума СК код новорођенчади је виши у односу на старије, с тим да се он изјед- начава након десет дана живота (Clarkson et al., 2006). У раној трудноћи, ниво СК се повећава у односу на каснију трудноћу током које се региструје висок ниво СК-MB (Brancaccio et al., 2007).

Млади мушкарци имају висок ниво СК, који се лагано смањује током одрастања и старења (Brancaccio et al., 2007).

У односу на расу, црнци имају више вредности СК у односу на белце, мада су нека истраживања показала да не постоје расне разлике у нивоу СК код спортиста и поред чињенице да су црнци генерално тежи и имају већу густину костију од људи беле pace (Brancaccio et al., 2007).

Дакле, вредности СК показују велику варијабилност међу појединцима. Неки спортисти имају ниже реакције на физичку активност са хронично ниским нивоом СК у серуму. Други спортисти имају висок ниво одговора са вишим вредностима овог ензима. Постоји преломна тачка у концентрацији СК од 300-500 IU/l када се отпушта у крв после физичке активности. Ниво ензима СК зависи од мишићних карактеристика (Brancaccio et al., 2007). Шуман и Клаук (Schumann, Klauke 2003) су предложили граничне вредности СК које су 350 код мушкараца и $200 \mathrm{IU} / 1$ код жена. Друга студија показује другачије границе за мушкарце, 391 и $398 \mathrm{IU} / 1$ и 240 и $207 \mathrm{IU} / 1$ за жене (Mougios, 2007). Главна разлика између резултата појединих студија вероватно је због различитог нивоа тренираности испитаника, као и спортиста различитих спортских грана и дисциплина који учествују у истраживањима. Наиме, уколико спортиста и неспортиста раде исти тест физичке активности, ниво у серуму СК спортиста је нижи од оних забележен код контролне групе неспортиста (Nigro et al., 1983, Anugweje, Okonoko, 2012). Такође, велики пораст нивоа серумске СК комбинован са смањеном толеранцијом на напор може бити маркер претренираности (Anugweje, Okonoko, 2012). Време ослобађања СК превасходно зависи од нивоа тренираности, типа, интензитета и трајање активности. Након продуженог вежбања, активности укупног серумског СК значајно се повећава у току 24 сата након вежбања. Међутим, ако спортиста настави да тренира, ниво СК може остати повећан много дуже (Clarkson, Hubal, 2008). Hajвеће вредности серумске СК настају 8 сати након тренинга снаге. 


\section{КРЕАТИН КИНАЗА КОД СПОРТИ- СТА РАЗЛИЧИТИХ СПОРТСКИХ ГРАНА И ДИСЦИПЛИНА}

Висок ниво серумске СК је забележен после дуготрајне физичке активности, као што је ултрамаратон (Fehrenbach et al., 2010), Ironman триатлон (Neubauer et al., 2008) и триатлон (Brancaccio et al., 2010), где је након ових активности неизбежан мишићни колапс. Ултратриатлон је повезан са високим променама активности СК (од 54 до 1849 IU/l), као и промене других маркера мишићног оштећења (Gastmann et al., 1998). Већина података праћења нивоа сермуске СК долази од дугопругаша, али постоје и студије које показују да и кратка физичка активност ексцентричног типа контракције мишића повећава ниво СК (Brancaccio et al., 2007).

Могис и сарадници (Mougios et al, 2007) мерили су активност СК код фудбалера и пливача, где је најнижи референтни ниво за фудбалере био 83 $\mathrm{IU} / 1$, док је за пливаче износио око 70 IU/l. Горња граница редом је била 1492 и 523 IU/l.

Велике промене у СК, као маркеру оштећења мишића ( $\left.900 \mathrm{IU} \cdot 1^{-1}\right)$, као и пад након 20 метара спринт теста $(-2 \%)$ и максималног скока $(-10 \%)$ након 24 сата од меча, примећено је код елитних младих фудбалера (Fatouros et al., 2010). Такође ce ठележи значајно повећање активности СК ( 1000 IU $\left.\cdot l^{-1}\right)$, после рагби меча (Takarada, 2003). У студији Ховатсона и Милака (Howatson, Milak, 2009) прати се стања упале мишића и активности ЦК $\left(\sim 800 \mathrm{IU} \cdot \mathrm{l}^{-1}\right), 24$ сата након 15 спринтева на 30 метара код младих атлетичара. Мореира и сарадници (Moreira et al., 2014) у својој студији указују да анализирана кошаркашка утакмица „доводи“ до благе упале мишића и да се након исте не региструје велико отпуштање протеина из мишића. Ови подаци могу указати и на то да су врхунски спортисти отпорни на велике осцилације СК и могућа транзициона оштећења мишића. Гил и сарадници (Gill et al., 2006) су пратили рагбисте и утврдили да је ниво СК пре и после утакмице веома висок, редом 1023.0 (308.3) и 2194.0 (833.7) IU/l. Примећене су и негативне последице оштећења мишића код тенисера са смањеном продукцијом јачине, што може да утиче на перформансе током меча (Gomes et al., 2014). Највише вредности сваког играча у студији биле су од 105 до 498 IU. $1^{-1}$, а значајно повећање активности СК у плазми забележене су 24 и 48 сати након меча.

\section{НИВО СЕРУМА СК - ИЗАЗОВ ЗА ТЕХНОЛОГИЈУ ТРЕНИНГА}

У циљу повећања перформанси вежбања и смањења оштећења мишића, студије и истраживања покушавају да одгонетну најефикаснији начин опоравка организма након физичке активности. У том циљу, бројни су суплементи и методе које су нашле примену у пракси, са или без оправданих разлога.

\section{Стање хидрираности и креатин киназа}

Бројне су студије у вези са коришћењем течности у току тренажног процеса (вода, сокови, енергетска пића), као и студије које се баве утицајем дехидратације на организам и физичке перформансе. Озкан и Ибрахим (Ozkan, Ibrachim, 2016) су испитивали да ли постоји разлика између рвача који јесу и који нису дехидрирани и открили да постоји висок ниво серумске СК код дехидриране групе, што се негативно одражавало на перформансе због бола у мишићима. Друга студија је испитивала конзумирање зеленог чаја током вежठања и закључила да је зелени чај одличан антиоксиданс, као и да смањује отпуштање СК током вежбања (Kuo et al., 2015). Конзумацијом сока црне рибизле после високоинтензивног тренинга смањује се оштећење и упала мишића редуковањем нивоа СК 48 до 96 сати након вежбања (Hutchison et al., 2016). Конзумирање електоркинетички модификоване воде значајно се смањује мишићно оштећење изазвано вежбањем и убрзава опоравак (Borsa et al.,2013).

\section{Суплементација и ниво креатин киназе}

Један од суплемената, кад је реч о редукцији оштећења мишића, тиме и нивоа серумске СК активности, који се широко користи у опоравку након активности високог интензитета је креатин (Kim et al., 2015). Комбинација суплементације амино киселином из групе ВСАA (branched chain amino acid) и таурином, као и препаратима из групе антиупалних и антиоксидативних киселина, може бити ефикасно средство одлагања упале мишића и мишићног оштећења ( $\mathrm{Ra}$ et al., 2013). Са друге стране, исти аутори су закључили да суплементација само таурином не утиче на ниво СК код здравих особа након вежбања. Фуре и сарадници (Fouré et al., 2010) су утврдили да оштећени мишић није у стању да преузме 
бенефите конзумирања ВСАА након вежбања. Такође, друга студија закључује да суплементација амино-киселином пре и после 100 километара ултрамаратона такође нема ефекта на ниво СК у серуму (Knechtle et al., 2011). Узимање куркумина повећава снагу и трајање вежбања и смањује ниво СК после физичке активности (Huang et al., 2015), такође одлаже упалу мишића, што је повезано са нижим вредностим СК у крви (Nicol et al., 2015) и редукује симптоме оштећења мишића изазваног вежбањем (McFarlin et al., 2016). Суплементација шафраном (10 дана по 300 мг) такође има превентивни ефекат на упалу мишића и значајно смањује концентрацију СК, као и да 4 грама ђумбира након вежбања убрзава опоравак организма, али не утиче на оштећење и одлагање упале мишића (Matsumura et al., 2015).

\section{Криотерапија и креатин киназа}

Према новијим истраживањима, третман потапања у хладну воду нема ефекта као што се раније мислило. Такеда и сарадници (Takeda et al., 2014) нису утврдили да хладна вода има ефекта на ниво СК после рагби и фудбалског меча. Потапање у хладну воду одмах и након 24 сата од утакмице није утицало на праћене индикаторе физичких перформанси (Rupp et al., 2012), односно само потапање тела прате минимални ефекти на одлагање упале мишића (Glasgow et al., 2014). Meђутим, Машадо и сарадници (Machado et al., 2016) указују да потапање у воду, температуре између 11 и $15^{\circ} \mathrm{C}$,у времену од 11 до 15 минута, може имати ефекта.

\section{Креатин киназа и ефекти масаже и терапија вибрацијом}

Нема јасних евиденција о ефектима масаже у комбинацији са хипоксијом у поређењу са применом само масаже на ниво СК после фудбалске утакмице (Gatterer et al., 2013). Терапија вибрацијом целог тела након вежбања показује мањи притисак, бол и упалу мишића уз мање смањење максималне изометријске и изокинетичке силе мишића и нижег нивоа креатин киназе у крви (Veqar, Imtiyaz, 2014). Насупрот овом, терапија вибрацијом није ефикаснија од стандардне масаже и истезања када је реч о нивоу СК после вежठања (Fuller et al., 2015).

\section{ДРУГИ МАРКЕРИ И ОШТЕКЕЊА МИШИЋА}

С обзиром на претходна истраживања и искуства, може се закључити да не постоји јединствени маркер који ठи био сигуран показатељ пролазних оштећења мишића и претренираности. Научници препоручују коришћење више од једног маркера у проналажењу одговора. Серумске активности ензима, попут креатин киназе (CK), аспартат аминотрансферазе (AST), аланин аминотрансфераза (ALT), лактат дехидрогеназе (LDH), алдолаза (ALD), тропонина и миоглобина се користе као индиректни маркери оштећења мишића изазваног вежбањем (Brancaccio et al., 2010). Што се више маркера узме у разматрање, то ће могући закључци бити прецизнији.

Серум лактат дехидрогеназе (LDH) је маркер оштећења ћелија чије специфично повећање у изоензимима може бити корисно за постављање дијагнозе код нетрауматске акутне рабдомиолизе (Brancaccio et al., 2010).

Алдолаза може да се користи заједно са СК за процену стања мишића адаптације на тренинг (Brancaccio et al., 2010). Код хроничних мишићних повреда повећани су како аспартат трансфераза (AST), тако и аланин аминотрансфераза (ALT) (Nathwani et al., 2005) и ретко је повећана код људи који нису болесни и који имају нормалну активност СК, сугеришући на постојање AST макроензима (Cabrera-Abrev et al., 2008).

Код неких спортиста повећање серума AST требало би разматрати заједно са активношћу СК (Brancaccio et al., 2010). Миоглобин је користан маркер за праћење ефикасности оптерећења мишићног ткива на тренингу (Speranza et al., 2007).

Истраживања су дошла до закључка да код миопатије, постоји блиска корелација између $\operatorname{TnT}$ (једна од две изоформе тропонина) и СК (Collinson et al., 1995). Код пацијената са хрончном болешћу мишића повећана је концентрација TnT (Prellwitz et al., 1996).

Карбоник анхидраза III је још један користан маркер оштећења мишића и то из разлога што је присутан у скелетном мишићу, али не и у миокарду и ослобађа се у крвоток након повреде (Fu et al., 2009). Повећање и смањење његове концентрације је брже него код алдолазе, СК, AST и LDH (Shima, 1984). Који год маркер да се узме у разматрање, допуном са једним или више њих ће 
се само показати тачнији резултати, јер ни један од њих, сам по себи, није довољан за релијабилно закључивање.

\section{ОГРАНИЧЕЊА У ПРИМЕНИ РЕЗУЛТАТА ПРАЋЕЊА КРЕАТИН КИНАЗЕ}

Креатин киназа се широко користи као маркер за дијагнозу болести мозга, срца и мишића (Brancaccio et al., 2006). У нормални условима и стању организма, серум СК се у мишићима може наћи у облику СК-ММ, у мозгу СК-ВВ и СК-МБВ у срцу. Међутим, постоје ситуације где се у мишићима може наћи и СК-МВ, као што је случај са ултрамаратонцима (Denvir et al., 1999), као и СК-ВВ код боксера (Brancaccio et al., 2007). Ниво СК расте 6 сати после вежбања и може остати повишен и два дана након вежбања. Ако се после овог периода и даље показује присуство ових изоензима у мишићима ради се о неком нефизиолошком стању. Неке особе које после вежбања имају веома високе вредности СК могу имати неку врсту мишићне болести што захтева додатне анализе. Повећане вредности нивоа СК код здравих неспортиста захтевају даље истраживање (Brancaccio et al., 2006).

Ниво СК може такође бити повишен конзумирањем дроге, због астме, хипотироидизма, коришћења анаболичких стероида (Dekkers et al., 1996). Уколико дође до повећања нивоа СК и нетипичних симптома, биопсија мишића је најбољи начин дијагнозе. Она је до сада детерминисала да: $18 \%$ оваквих пацијената пати од мишићне болести, скоро 39\% има атипичне мишићне аномалије, док је остатак испитаника био нормалног здравља (Stanhouders et al., 1999). Једна од најзначајнијих улога креатин киназе је у чињеници да праћење његовог нивоа пре и после вежбања може указати на миопатију и ठез биопсије мишића која је далеко инвазивнија метода (Brancaccio et al., 2010). Међутим, повећање нивоа серума СК не мора нужно да буде последица вежбања и оштећења мишића изазваног вежбањем. Са друге стране, постоје спортисти који немају никакве симптоме примењене спортске активности. Повећањем интензитета и обима вежбања може се приступити оваквим спортистима, али у том случају постоји могућност негативног ефекта продуженог вежठања и тренинга у виду губљења мишићних протеина (Brancaccio et al., 2006).

\section{НОВИ ИНДИКАТОРИ У ПРОЦЕНИ ПРОЛАЗНИХ ОШТЕКЕЊА МИШИЋА}

Нова открића би требало да иду у смеру што тачније детекције оштећења мишића, проналаску што бржег, тачнијег, дискриминативног и специфичног маркера, који би ठио приступачан, лако мерљив и јефтин, чије мерење указује искључиво на транзиционо оштећење мишића, ठез повезивања са могућим патолошким стањима организма. Пракси недостаје маркер који би био ефикасан и са мањом амплитудом измерених вредности, као што је до сада то случај (Brancaccio et al., 2011). Тaкав маркер би требао указивати на разлике у односу на пол, индивидуалне разлике и исте разлике ठез обзира који део тела је подвргнут физичкој активност (Koch et al., 2014). С обзиром на то, требало би дефинисати тачан и јединствен протокол мерења, што до сада није био случај. Један од будућих маркера, који је у процесу истраживања и детекције и који би могао да замени остале, до сада познате маркере оштећења мишића, јесте гонидо сирћетна киселина (GAA). Као природни прекурсор креатина, у условима када је доступност креатина несметана, улога GAA као супстрата је занемарљива, док, са друге стране, приликом дефицита креатина она може у потпуности да засити креатин киназу и да делује као заменски фосфаген (Остојић, 2015). Резултати студије која је истраживала утицај тренинга издржљивости (трчање на тредмилу) и тренинга репетитивне снаге (потисак с клупе до отказа) на ниво концентрације GAA и креатина указују на то да се ниво креатина повећао код обе врсте вежбања, нарочито при трчању, као и да је концентрација GAA значајно опала у оба случаја, више код тренинга трчања (Štajer et al., 2016). Закључак ове студије је управо тај да се у будућности серумски ниво GAA може користити као нови биомаркер замора код физички активне популације.

\section{ЗАКЉУЧАК}

Креатин киназа (СК) је један од неколико маркера оштећења мишића изазваног вежбањем. Ниво СК остаје подигнут углавном 24 сата након вежбања, након чега се враћа на почетни ниво. 
Ако након тог времена остане и даље повишен, вероватно је у питању претренираност. Поред тога, оштећење мишића може се појавити након физиолошких и патолошких стања. Бољу процену и компактну слику стања мишића дају тест крви и урина.

Ниво креатин киназе зависи од бројних фактора, као што су пол, раса, телесна тежина, физичка активност, итд. Висок ниво СК код здравих особа је углавном повезан са тренингом.

\section{ЛИТЕРАТУРА}

1. Anugweje, K. C., \& Okonko, I. O. (2012). Effect of Noni Supplementation on the Serum Creatine Kinase (CK) Levels of Athletes. World J. Sport Sci., 7, 41-47.

2. Borsa, P. A., Kaiser, K. L., \& Martin, J. S. (2013). Oral consumption of electrokinetically modified water attenuates muscle damage and improves postexercise recovery. Journal of Applied Physiology, 114(12), 1736-1742.

3. Brancaccio, P., Limongelli, F. M., \& Maffulli, N. (2006). Monitoring of serum enzymes in sport. British journal of sports medicine, 40(2), 96-97.

4. Brancaccio, P., Lippi, G., \& Maffulli, N. (2010). Biochemical markers of muscular damage. Clinical Chemistry and Laboratory Medicine, 48(6), 757767.

5. Brancaccio, P., Maffulli, N., \& Limongelli, F. M. (2007). Creatine kinase monitoring in sport medicine. British medical bulletin, 81(1), 209-230.

6. Brancaccio, P., Maffulli, N., Politano, L., Lippi, G., \& Limongelli, F. M. (2011). Persistent HyperCKemia in Athletes. Muscles, ligaments and tendons journal, 1(1), 31.

7. Cabrera-Abreu, J., Jain, R., Robinson, P., Edees, S., \& Staughton, T. (2008). A case of aspartate aminotransferase macroenzyme. Annals of clinical biochemistry, 45(3), 320-322.

8. Clarkson, P. M., \& Hubal M. J. (2008). Exercise-induced muscle damage in humans. American journal of physical medicine \& rehabilitation, 81(11): 52-69.

9. Clarkson, P. M., Kearns A. K., Rouzier, P., Rubin, R., \& Thompson, P. D.(2006). Serum creatine kinase levels and renal function measures in exertional muscle damage. Medicine and science in sports and exercise. 38(4): 623.

10. Collinson,P.O., Chandler,H.A., Stubbs, P.J., Moseley, D.S., Lewis, D., \& Simmons, M.D. (1995).
Највише вредности СК су утврђене углавном код дугопругаша и дугих тренинга, као што је ултрамаратон, активности које захтевају ексцентричну контракцију мишића.

Процена СК пре и после физичке активности је „дијагностички алат“ за откривање миопатија, што је далеко мање инвазивно него што је потребно за биопсију мишића. Ово је вероватно најважнија употреба серумске креатин киназе у дијагностичке сврхе у спорту и физичкој активности.

Measurement of serum troponin $\mathrm{T}$, creatine kinase $\mathrm{MB}$ isoenzyme, and total creatine kinase following arduous physical training. Ann Clin Biochem 32: 450-3.

11. Dekkers,J.C., van Doornen, L.J., \& Kemper, H.C. (1996). The role of antioxidant vitamins and enzymes in the prevention of exercise induced muscle damage. Sports Med, 21:213-38.

12. Denvir, M.A., Galloway, P.J., Meighan, A.S., Blyth, M., Alexander, C., \& Fleming, C. (1999). Changes in skeletal and cardiac muscle enzymes during the Scottish Coast to Coast Triathlon. Scott Med $J$, 44: 49-51.

13. Fatouros, I. G., Chatzinikolaou, A., Douroudos, I. I., Nikolaidis, M. G., Kyparos, A., Margonis, K., ... \& Mandalidis, D. (2010). Time-course of changes in oxidative stress and antioxidant status responses following a soccer game. The Journal of Strength \& Conditioning Research, 24(12), 32783286.

14. Fehrenbach, E., Niess, A. M., Schlotz, E., Passek, F., Dickhuth, H. H., \& Northoff, H. (2000). Transcriptional and translational regulation of heat shock proteins in leukocytes of endurance runners. Journal of Applied Physiology, 89(2), 704710.

15. Fouré, A., Nordez, A., \& Cornu, C. (2010). Plyometric training effects on Achilles tendon stiffness and dissipative properties. Journal of Applied Physiology, 109(3), 849-854.

16. Fu, F., Nie, J., \& Tong, T. K. (2009). Serum cardiac troponin $\mathrm{T}$ in adolescent runners: effects of exercise intensity and duration. International journal of sports medicine, 30(03), 168-172.

17. Fuller, J. T., Thomson, R. L., Howe, P. R., \& Buckley, J. D. (2015). Vibration therapy is no more 
effective than the standard practice of massage and stretching for promoting recovery from muscle damage after eccentric exercise. Clinical Journal of Sport Medicine, 25(4), 332-337.

18. Gastmann, U., Dimeo, F., Huonker, M., Bocker, J., Steinacker, J. M., Petersen, K. G., ... \& Lehmann, M. (1998). Ultra-triathlon-related blood-chemical. J Sports Med Phys Fitness, 38, 18-23.

19. Gatterer, H., Schenk, K., Wille, M., Murnig, P., \& Burtscher, M. (2013). Effects of massage under hypoxic conditions on exercise-induced muscle damage and physical strain indices in professional soccer players. Biology of sport, 30(2), 81.

20. Gill, N. D., Beaven, C. M., \& Cook, C. (2006). Effectiveness of post-match recovery strategies in rugby players. British journal of sports medicine, 40(3), 260-263.

21. Glasgow, P. D., Ferris, R., \& Bleakley, C. M. (2014). Cold water immersion in the management of delayed-onset muscle soreness: Is dose important? A randomised controlled trial. Physical therapy in sport, 15(4), 228-233.

22. Gomes, R. V., Santos, R. C. O., Nosaka, K., Moreira, A., Miyabara, E. H., \& Aoki, M. S. (2014). Muscle damage after a tennis match in young players. Biology of sport, 31(1), 27.

23. Haramizu, S., Ota, N., Hase, T., \& Murase, T. (2011). Catechins attenuate eccentric exercise-induced inflammation and loss of force production in muscle in senescence-accelerated mice. Journal of Applied Physiology, 111(6), 1654-1663.

24. Heled, Y., Bloom, M. S., Wu, T. J., Stephens, Q., \& Deuster, P. A. (2007). CM-MM and ACE genotypes and physiological prediction of the creatine kinase response to exercise. Journal of Applied Physiology, 103(2), 504-510.

25. Howatson, G., \& Milak, A. (2009). Exercise-induced muscle damage following a bout of sport specific repeated sprints. The Journal of Strength \& Conditioning Research, 23(8), 2419-2424.

26. Huang, W. C., Chiu, W. C., Chuang, H. L., Tang, D. W., Lee, Z. M., Wei, L., ... \& Huang, C. C. (2015). Effect of curcumin supplementation on physiological fatigue and physical performance in mice. Nutrients, 7(2), 905-921.

27. Hutchison, A. T., Flieller, E. B., Dillon, K. J., \& Leverett, B. D. (2016). Black currant nectar reduces muscle damage and inflammation following a bout of high-intensity eccentric contractions. Journal of dietary supplements, 13(1), 1-15.
28. Kim, J., Lee, J., Kim, S., Yoon, D., Kim, J., \& Sung, D. J. (2015). Role of creatine supplementation in exercise-induced muscle damage: A mini review. Journal of exercise rehabilitation, 11(5), 244.

29. Knechtle, B., Knechtle, P., Mrazek, C., Senn, O., Rosemann, T., Imoberdorf, R., \& Ballmer, P. (2011). No effect of short-term amino acid supplementation on variables related to skeletal muscle damage in $100 \mathrm{~km}$ ultra-runners-a randomized controlled trial. Journal of the International Society of Sports Nutrition, 8(1), 6.

30. Koch, A. J., Pereira, R., \& Machado, M. (2014). The creatine kinase response to resistance exercise. J Musculoskelet Neuronal Interact, 14(1), 6877.

31. Kuo, Y. C., Lin, J. C., Bernard, J. R., \& Liao, Y. H. (2015). Green tea extract supplementation does not hamper endurance-training adaptation but improves antioxidant capacity in sedentary men. Applied Physiology, Nutrition, and Metabolism, 40(10), 990-996.

32. Machado, A. F., Ferreira, P. H., Micheletti, J. K., de Almeida, A. C., Lemes, I. R., Vanderlei, F. M., ... \& Pastre, C. M. (2016). Can water temperature and immersion time influence the effect of cold water immersion on muscle soreness? A systematic review and meta-analysis. Sports Medicine, 46(4), 503-514.

33. Malaguti, M., Angeloni, C., Garatachea, N., Baldini, M., Leoncini, E., Collado, P. S., ... \& Hrelia, S. (2009). Sulforaphane treatment protects skeletal muscle against damage induced by exhaustive exercise in rats. Journal of Applied Physiology, 107(4), 1028-1036.

34. Matsumura, M. D., Zavorsky, G. S., \& Smoliga, J. M. (2015). The effects of pre-exercise ginger supplementation on muscle damage and delayed onset muscle soreness. Phytotherapy Research, 29(6), 887-893.

35. McFarlin, B. K., Venable, A. S., Henning, A. L., Sampson, J. N. B., Pennel, K., Vingren, J. L., \& Hill, D. W. (2016). Reduced inflammatory and muscle damage biomarkers following oral supplementation with bioavailable curcumin. $B B A$ clinical, 5, 72-78.

36. Meamarbashi, A., \& Rajabi, A. (2015). Preventive Effects of 10-Day Supplementation With Saffron and Indomethacin on the Delayed-Onset Muscle Soreness. Clinical Journal of Sport Medicine, 25(2), 105-112. 
37. Moreira, A., Nosaka, K., Nunes, J. A., Viveiros, L., Jamurtas, A. Z., \& Aoki, M. S. (2014). Changes in muscle damage markers in female basketball players. Biology of sport, 31(1), 3.

38. Mougios, V. (2007). Reference intervals for serum creatine kinase in athletes. British journal of sports medicine, 41(10), 674-678.

39. Nathwani, R. A., Pais, S., Reynolds, T. B., \& Kaplowitz, N. (2005). Serum alanine aminotransferase in skeletal muscle diseases. Нераtology, 41(2), 380-382.

40. Neubauer, O., König, D., \& Wagner, K. H. (2008). Recovery after an Ironman triathlon: sustained inflammatory responses and muscular stress. European journal of applied physiology, 104(3), 417426.

41. Newham, D. J., Jones, D. A., \& Clarkson, P. M. (1987). Repeated high-force eccentric exercise: effects on muscle pain and damage. Journal of Applied Physiology, 63(4), 1381-1386.

42. Nicol, L. M., Rowlands, D. S., Fazakerly, R., \& Kellett, J. (2015). Curcumin supplementation likely attenuates delayed onset muscle soreness (DOMS). European journal of applied physiology, 115(8), 1769-1777.

43. Nigro, G., Comi, L. I., Limongelli, F. M., Giugliano, M. A. M., Politano, L., Petretta, V., ... \& Stefanelli, S. (1983). Prospective study of X-linked progressive muscular dystrophy in campania. Muscle \& nerve, 6(4), 253-262.

44. Ostojić, S. M. (2015). Cellular bioenergetics of guanidinoacetic acid: the role of mitochondria. Journal of bioenergetics and biomembranes, 47(5), 369-372

45. Ozkan, I., \& Ibrahim, C. H. (2016). Dehydration, skeletal muscle damage and inflammation before the competitions among the elite wrestlers. Journal of physical therapy science, 28(1), 162-168.

46. Prellwitz, W., Hafner, G., Rupprecht, H. J., \& Meyer, J. (1996). Diagnostic and differential diagnostic value of troponins. Medizinische Klinik (Munich, Germany: 1983), 91(6), 336-342.

47. Ra, S. G., Miyazaki, T., Ishikura, K., Nagayama, H., Komine, S., Nakata, Y., ... \& Ohmori, H. (2013). Combined effect of branched-chain amino acids and taurine supplementation on delayed onset muscle soreness and muscle damage in high-intensity eccentric exercise. Journal of the International Society of Sports Nutrition, 10(1), 51.
48. Rupp, K. A., Selkow, N. M., Parente, W. R., Ingersoll, C. D., Weltman, A. L., \& Saliba, S. A. (2012). The effect of cold water immersion on 48-hour performance testing in collegiate soccer players. The Journal of Strength \& Conditioning Research, 26(8), 2043-2050.

49. Schumann, G., \& Klauke, R. (2003). New IFCC reference procedures for the determination of catalytic activity concentrations of five enzymes in serum: preliminary upper reference limits obtained in hospitalized subjects. Clinica chimica acta, 327(1-2), 69-79.

50. Shima, K. (1984). Human muscle carbonic anhydrase III (CA-III). Purification, immunohistochemical localization in the human skeletal muscle and its clinical application to the neuromuscular disease. [Hokkaido igaku zasshi] The Hokkaido journal of medical science, 59(2), 98-116.

51. Speranza, L., Grilli, A., Patruno, A., Franceschelli, S., Felzani, G., Pesce, M., ... \& Felaco, M. (2007). Plasmatic markers of muscular stress in isokinetic exercise. Journal of biological regulators and homeostatic agents, 21(1/2), 23.

52. Stadhouders, A. M., Jap, P. H., Winkler, H. P., Eppenberger, H. M., \& Wallimann, T. (1994). Mitochondrial creatine kinase: a major constituent of pathological inclusions seen in mitochondrial myopathies. Proceedings of the National Academy of Sciences, 91(11), 5089-5093.

53. Štajer, V., Trivic, T., Drid, P., Vranes, M., \& Ostojic, S. M. (2016). A single session of exhaustive exercise markedly decreases circulating levels of guanidinoacetic acid in healthy men and women. Applied Physiology, Nutrition, and Metabolism, 41(10), 1100-1103.

54. Takarada, Y. (2003). Evaluation of muscle damage after a rugby match with special reference to tackle plays. British journal of sports medicine, 37(5), 416-419.

55. Takeda, M., Sato, T., Hasegawa, T., Shintaku, H., Kato, H., Yamaguchi, Y., \& Radak, Z. (2014). The effects of cold water immersion after rugby training on muscle power and biochemical markers. Journal of sports science \& medicine, 13(3), 616.

56. Veqar, Z., \& Imtiyaz, S. (2014). Vibration therapy in management of delayed onset muscle soreness (DOMS). Journal of clinical and diagnostic research: JCDR, 8(6), LE01. 


\title{
CREATINA QUINASA COMO INDICADOR DEL DAÑO TRANSITORIO DE LOS MÚSCULOS - ANÁLISIS Y SIGNIFICADO PARA LA TECNOLOGÍA DE ENTRENAMIENTO DEPORTIVO PRINT-A-MAIL
}

\begin{abstract}
Resumen
Las investigaciones de hasta el momento demuestran que no existe un marcador único que sería el indicador suficientemente fiable del daño muscular y de sobreentrenamiento. Seguir varios indicadores fisiológicos puede llevar hasta la respuesta deseada. Entre ellos está también el suero de creatina quinasa como uno de los mejores indicadores del daño muscular que acompaña la actividad física. Además de otras características, ella es el indicador directo del daño muscular y de sobreentrenamiento. El objetivo del presente trabajo es organizar los conocimientos publicados en las revistas científicas relevantes, referidos directamente a la creatina quinasa y sus vínculos con otros marcadores, así como también, el límite de su uso. Midiendo el nivel de creatina quinasa antes y después de los ejercicios se puede predeterminar la existencia de miopatía sin la biopsia del musculo, lo que es una de las funciones más importantes de este suero. En el futuro, las investigaciones deberían abarcar también otros factores que indican los daños musculares y sobreentrenamiento, su actividad sinérgica, pero también nuevos descubrimientos en la estimación de los daños musculares transitorios por la actividad física.
\end{abstract}

Palabras claves: CREATINA QUINASA/ SOBREENTRENAMIENTO/ DAÑO MUSCULAR /DEPORTE/ TECNOLOGÍA DE ENTRENAMIENTO

Примљен: 02.10.2017

Прихваћен: 27.11.2017 